\title{
Chapter 6 \\ The Negative Effect Factors of the Land Acquisition System for Profit-Oriented Enterprises in Order to Promote Economic Growth
}

\author{
Yuichi Ohya
}

\begin{abstract}
The Land Acquisition (Amendment) Act of 1991 in Malaysia for economic growth has institutionally enabled arbitrary land acquisition. This paper reveals what is the fundamental determinant of the negative effects on the legal system concerning land acquisition for economic growth. As a result of this study consideration, the article of property rights within the limits of the law enables governments to have a broad discretionary power and liberalizes policies governments can implement. However, this study concludes policies that make light of personal assets will obstruct economic growth in the long run.
\end{abstract}

Keywords Land Acquisition Act in Malaysia - Public vs. profit-oriented land acquisition · Economic growth $\cdot$ Flexible discretion to management $\cdot$ Social welfare

\subsection{Introduction}

The land acquisition system in Malaysia is a system that forces the provision of land it owns with compensating the land owners by the state authority with power to acquire land for public purposes and economic development.

\footnotetext{
The original title was "The Negative Effect Factors of $t^{1}$ he Land Acquisition System that Encompasses Non-Public Purpose for Economic Growth", but in this book with emphasis on simplicity, it is described as "The Negative Effect Factors of the Land Acquisition System for Profit-Oriented Enterprises in order to Promote Economic Growth". Also, in the text, some sentences were revised as the notation was changed from "land acquisition for non-public purpose" to "land acquisition for profit-oriented enterprises".
}

Y. Ohya $(\bowtie)$

Yokohama City University, Yokohama, Japan

e-mail: y_ohya@yokohama-cu.ac.jp

Y. Asami et al. (eds.), Frontiers of Real Estate Science in Japan, New Frontiers in

Regional Science: Asian Perspectives 29,

https://doi.org/10.1007/978-981-15-8848-8_6 
In ASEAN countries, land acquisition (land recovery in Vietnam and Land Requisition in Laos) for public purposes has been established. Excluding Myanmar and Laos, specific requirements of land acquisition, for example social capital development and national security, etc., have been stipulated.

Vietnam and Malaysia, in particular, are characterized by admitting land acquisition for economic development in addition to land acquisition for public purposes. The advantage of land acquisition for economic development is to increase land use efficiency and promote economic growth by transferring land ownership to more productive operators. Land recover for economic growth in Vietnam is limited to the construction of industrial parks, etc., but the area where land acquisition is possible in Malaysia is not limited under the Land Acquisition Act 1960. In addition, Malaysia's land acquisition is permitted to provide land for corporations to conduct profit-oriented enterprises, and these are different from Vietnam. ${ }^{1}$

As an institutional issue of land acquisition for profit-oriented enterprises, bribery can be caused because it is directly linked to the profits of private companies. The existence of bribery is a problem in many countries. This study examines the negative impacts on the implementation of economic policy when the operation of land acquisition for profit-oriented enterprises and bribery are linked and what kind of factors it depends on in the legal system design.

The structure of this article is as follows. In Chap. 2, the existing research is organized, and the viewpoints of consideration are arranged from the viewpoint of the negative effect factor of land acquisition system and land acquisition in each country. Chapter 3 confirms the transition of economic policy after the independence of Malaysia and background of Land Acquisition Amendment Act of 1991 and analyzes the changes in income inequality in Malaysia. It also shows the difference between the acquisition requirements of the Land Acquisition Act enacted in 1960 and the 1991 Amendment Act. In addition, this chapter indicates results of survey on corruption and bribery in Malaysia and the bribery of state government-related parties revealed in court are presented. Chapter 4 organizes the Malaysian legal system from the provisions of the federal constitution that restrains the administration and conditions the legislation with regard to the characteristic of the separation of three powers, property rights, and the allocation of power between the federation and state on land administration. In Chap. 5, based on the matters confirmed so far, this study considers institutional issues in land acquisition for profit-oriented enterprises and negative effect factors to economic policy, and shows the conclusion.

\footnotetext{
${ }^{1}$ In addition, except in the case of voluntary acquisition, the amount of compensation for land acquisition is determined by the administration in Malaysia. This point is different from Vietnam. Ishida (2006) reports that with regard to compensation for land recovery under the 2003 Revised Land Act in Vietnam, if an agreement has been reached between the landowner and the business operator, the agreed amount is adopted as the amount of compensation for the land recovery.
} 


\subsection{Review of Previous Studies}

\subsubsection{Land Acquisition}

The application of land acquisition to agricultural land has become prominent in rapidly industrializing countries, especially China and India (Ghatak and Mookherjee 2014). Ghatak and Mookherjee (2014) analyze the compensation policy for farmers who expropriated farmland during the process of industrialization. Dell'Angelo et al. (2017) show that commons are targeted for land acquisition in 44 of 56 cases in 27 countries. More than half of that were small farm lands.

As a matter of dealing with land acquisition in the Asian region, Miyamoto (1993) conducts a comparative study on public land acquisition systems in Malaysia, Thailand, Indonesia, and the Philippines. Ooi and Sirmans (2004) prove the existence of the wealth effects on land acquisition in Singapore.

Regarding land recovery in Vietnam, Ishida (2006) clarifies institutional changes brought about by the marketization of land use rights and the issues raised by land recovery disputes aimed at economic development. Tuyen et al. (2014) quantify the impact of farmland losses on household livelihoods. Tuyen et al. (2014) find no econometric evidence for the negative impacts of farmland losses on income and expenditure per adult equivalent. In addition, Tuyen et al. (2014) show that farmland loss has an indirect positive impact on household welfare, via its positive impact on the choice of nonfarm-based livelihoods.

Looking at other than ASEAN, Ju et al. (2016), which investigated land acquisition in China, prove how land acquisition in urbanization affects labor allocation decisions of farmers. The results show that land reduction has a significantly positive effect on the probability and share of household nonfarm labor allocation. As for the harmful effect of land acquisition in China, Hiramatsu (2012) points out that no uniform law has been enacted in the acquisition system and shows concern that administrative legislation that is haphazardly enacted and abolished is a factor which causes confusion in society. Jiang (2013) reports that the profits of land acquisition have led to overexploitation and bribery cases in China. Sato (2012) organizes economic and legal theoretical issues regarding the land acquisition problem in India.

The literature dealing with land acquisition in Latin America is scattered and not enumerated one by one, but there is a study dealing with land acquisition in Brazil (Miyasaka Porro and Shiraishi Neto 2014).

Previous studies dealing with land acquisition in Africa have been on the rise in recent years. Recent studies include German et al. (2013), Nolte and Voget-Kleschin (2014), and Kleemann and Thiele (2015). 


\subsubsection{Negative Effect Factors on Land Acquisition System}

In Japan, efficiency and justice (fairness or equality) are pointed out regarding the framework of legal system design discussed in administrative law (Hirai 1995; Abe 1996). Though it is necessary to examine how well the concept of welfare assumed by economics matches the meaning of welfare discussed in law, the discussion from the economic point of view on how to secure social welfare is not enough.

There are many empirical studies on corruption. In a recent study, Cooray et al. (2017) show that expanding corruption and shadow economy increases public debt. Beblavy (2007) proposes measures that increase the probability of exposing corruption and the cost of corruption, and reducing the benefits of corruption and the scope of administrative discretion so as to prevent corruption.

\subsubsection{Literature Related to Land Acquisition in Malaysia}

Xavier (2002) points out legislative problems in Malaysia's land acquisition from a legal perspective. Fujimoto (1997) does not show a quantitative evidence, but points out that the purposes of the amendment to Article 3 of the Act, which stipulates requirement for land acquisition, were to expand the manufacturing industry and to develop Malay reserve lands which have been delayed in land development. Salih and Yusof (1989) point out that there is still a lot of room for deregulation and liberalization of the economic structure of land as an issue of distribution policy after the completion of the New Economic Policy (NEP) implemented from 1971 to 1990. At the time of the 1995 general election, PAS (Partai Islam Semalaysia), an opposition party that led the government criticism campaign, increased the vote rate in the state where Malay farmers had criticized the government regarding land acquisition (Torii 1996). ${ }^{2}$ It cannot be denied that land acquisition due to the revision of the law provokes public oppositions.

Zhang (2005) and Pakhriazad and Shinohara (2005) show that the connection between business operators and politicians in Malaysia affects the business. Pakhriazad and Shinohara (2005) shows that administration can take wrong actions through bribery to politicians.

\footnotetext{
${ }^{2}$ Although PAS increased the vote rate as a whole, including Johor, which is called "UMNO state", the number of seats won was seven, unchanged from the 1990 general election. UMNO (United Malays National Organization) is the largest party of the ruling coalition (Torii 1996).
} 


\subsubsection{Summary}

Existing studies that simultaneously consider legal system design from three perspectives, administrative discretion, social welfare (social benefits), and corruption (bribery or bribe), are not sufficient. In addition, existing researches that consider land acquisition from two perspectives, system design and negative (harmful or abuse) effect (influence), are insufficient.

The amendment of the Land Acquisition Act in Malaysia in 1991 is a law revision as an economic policy. Hence, when considering such a law revision, it is necessary to consider not only the legal system but also its suitability as an economic policy. Studies about land acquisition in Malaysia have been accumulated on adequate compensation associated with land acquisition (Xavier 2002; Alias and Nasir Daud 2006; Alias et al. 2010), but studies dealing with trying to consider land acquisition simultaneously from both legal system and economic policy perspectives are not enough.

Therefore, this study focuses on Malaysia, which has introduced the land acquisition system for profit-oriented enterprises for the first time in ASEAN countries. ${ }^{3}$ Then, this study elucidates the negative effects of the combination of land acquisition for profit-oriented enterprises and bribery and reveals the institutional factors of these negative effects. The discussion focuses on institutional issues on land acquisition for profit-oriented enterprises and negative effect factors in economic policy from the case of land acquisition in Malaysia.

\subsection{Changes in Economic Policy after the Independence of Malaysia Leading to the Revision of the Land Acquisition Act in 1991}

This chapter provides an overview of Malaysia and analyzes the changes in income inequality in Malaysia, taking into account the changes in economic policies and the process leading to the revision of the Land Acquisition Act in 1991. In addition, this study compares the land acquisition requirements of the 1960 Land Acquisition Act and the 1991 Amendment Act and shows the results of investigation on corruption and bribery in Malaysia and the bribery of state government related parties revealed in court.

\footnotetext{
${ }^{3}$ Land recovery for economic development in Vietnam's 2003 Revised Land Law is clearly distinguished from land recovery for public purposes.
} 
Fig. 6.1 Gini coefficient, Malaysia 1970-2004. Source: Created by the author from Economic Planning Unit. Note: Data for $1970,1974,1976,1987$ peninsular Malaysia only

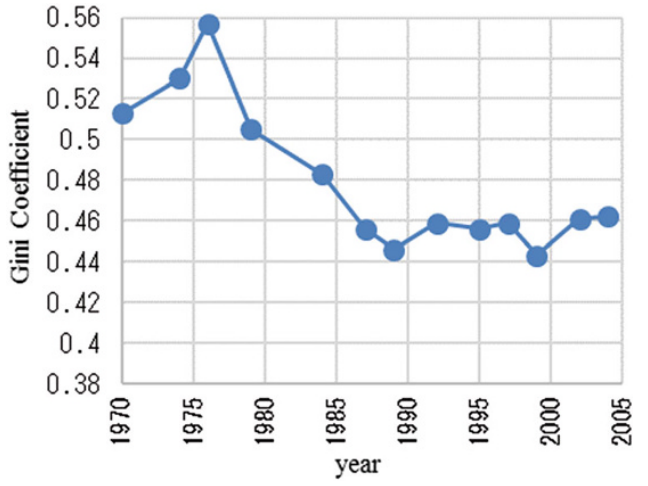

\subsubsection{Overview of Malaysia and Changes in Economic Policy}

Malaysia became independent from the United Kingdom on August 31, 1957, as the Federation of Malaya. In 1963, the Federation of Malaya was merged with the current Sabah and Sarawak States in Borneo to form Malaysia. ${ }^{4}$ Malaysia has a constitutional monarchy (Westminster-style parliamentary cabinet system) and is a federal state consisting of 13 states (11 Malay Peninsula and 2 North Borneo). Malaysia is a multi-racial country, and out of 30.99 million people as of 2015 , Bumiputra (meaning "Sons of the soil"), mainly Malays, accounted for $61.8 \%$, Chinese 21.4\%, and Indians 6.4\% (Department of Statistics, Malaysia n.d.). After its independence from the United Kingdom, Malaysia had adopted a liberal economic system called Lesser Fail which the government had not intervened in the market. However, NEP had introduced from 1971 to 1990 , triggered by the racial riots (13 May Riots) that occurred in 1969 due to the economic disparity between Malays and Chinese. ${ }^{5}$ NEP's policy objectives are to improve economic disparities between races and reduce poverty. The economic policy after the end of NEP was implemented to admit the temporary widening of inequality for economic growth from the realization that economic growth is necessary as a pre-stage of income redistribution. This direction can also be found in the Land Acquisition Act revised in 1991 after the end of the NEP. In fact, the Gini coefficient in the whole of Malaysia, which represents the level of income inequality, stopped at 0.446 in 1989. In the 1990s, the Gini coefficient had increased and stagnated between 0.456 and 0.459 until 1997. In 1999, the gap showed a narrowing of 0.443 , but after that the figure had risen again (Fig. 6.1) (Economic Planning Unit, Malaysia n.d.). After NEP (1971-1990), the National Development Policy (NDP) was implemented from 1991 to 2000.

Focusing on the Gini coefficient for each race (Fig. 6.2), the income gap among the same races had been widening until the late 1990s during the NDP period. The figure of Chinese showed a decrease prior to Bumiputra and Indians in 1997, but

\footnotetext{
${ }^{4}$ Singapore separated from Malaysia in 1965.

${ }^{5}$ The NEP is characterized by the Malay preferential, also known as the Bumiputra policy.
} 
Fig. 6.2 Gini coefficient by Ethnic Group 1970-2004. Source: Created by the author from Economic Planning Unit. Note: Data for $1970,1974,1976,1987$ peninsular Malaysia only

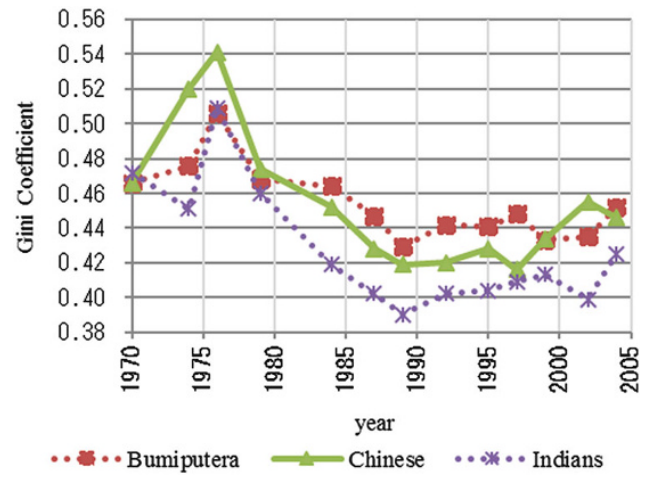

Table 6.1 Income disparities between races and regions (median)

\begin{tabular}{l|l|l|l}
\hline Year & Bumiputra/Chinese & Bumiputra/Indians & Rural/urban \\
\hline 1970 & $1: 2.23$ & $1: 1.62$ & $1: 1.91$ \\
\hline 1976 & $1: 2.06$ & $1: 1.55$ & $1: 1.97$ \\
\hline 1979 & $1: 1.94$ & $1: 1.54$ & $1: 1.83$ \\
\hline 1984 & $1: 1.82$ & $1: 1.33$ & $1: 1.74$ \\
\hline 1987 & $1: 1.73$ & $1: 1.31$ & $1: 1.61$ \\
\hline 1989 & $1: 1.73$ & $1: 1.31$ & $1: 1.59$ \\
\hline 1992 & $1: 1.76$ & $1: 1.33$ & $1: 1.86$ \\
\hline 1995 & $1: 1.76$ & $1: 1.36$ & $1: 1.85$ \\
\hline 1997 & $1: 1.84$ & $1: 1.48$ & $1: 1.87$ \\
\hline 2009 & $1: 1.75$ & $1: 1.38$ & $1: 1.80$ \\
\hline 2004 & $1: 1.74$ & $1: 1.34$ & $1: 2.00$ \\
\hline
\end{tabular}

Source: Created by the author from Economic Planning Unit

Note: Data for 1970 and 1976 peninsular Malaysia only

from 1997 to 2002, the figure of Chinese had shown a widening gap again. The Gini coefficient for Indians, Compared with Bumiputra and Chinese, had remained small, but the gap between Indians during the NDP period had been behind Bumiputra and Chinese.

Looking at income disparities among the races (Table 6.1), the income disparities between Bumiputra and the Chinese had been narrowing under the NEP, but the disparities had been widening until 1997 under the NDP. Similarly, the income gap between Bumiputra and the Indians had been shrinking under the NEP, but the gap had been widening until 1997 under the NDP. The income gap between Indians and Chinese had been narrowing until 1997, but since then it had been increasing until 2002 under the NDP.

The income gap between rural and urban areas had tended to narrow under the NEP, but the gap showed widening at the beginning of the NDP, and thereafter the gap narrowed in both 1995 and 1997 (Table 6.1). 
Based on these data transitions, the redistribution of income had seemed to work mainly from the late 1990s to the end of the NDP. Although the obtained data is not a yearly data, the Gini coefficient as a whole Malaysia during the 1990s NDP period shows a numerical decrease in 1995 and 1999. Also, in terms of income ratio between rural and urban areas, 1995 and 1999 showed a narrowing gap. ${ }^{6}$

\subsubsection{The Revision of Land Acquisition Act in 1991}

The amendment of the Land Acquisition Act in 1991 is the first year of the NDP. The Land Acquisition Act enacted in 1960 had limited the cases where land acquisition could be done to the public purpose case (Financial Times 1991). Article 3 of the Land Acquisition Act of 1960 stipulated that "The State Authority may acquire any land which is needed-(a) for any public purpose; (b) by any person or corporation undertaking a work which in the opinion of the State Authority is of public utility; or (c) for the purpose of mining or for residential, agricultural, commercial or industrial purposes" as a requirement for land acquisition.

\section{Expansion of Acquisition Requirements}

However, the Land Acquisition Amendment Act of 1991 expanded the requirement for land acquisition, and the State authority may acquire so as to provide land to any person or corporation for any project which in the opinion of the State Authority is beneficial to the economic development of Malaysia or any part thereof or any class of the public (Article 3 of Land Acquisition Amendment Act). As already indicated, income doubling and distribution plan are behind the revision of Article 3 of this Act which defines the requirement for land acquisition and as a plan of economic policy after the end of the NEP there is recognition that it is necessary to improve economic growth rate before income redistribution. The amendment of Article 3 is considered to be for the purpose of fulfilling policy goals.

In ASEAN countries, land acquisition (land recovery) for economic development is permitted not only in Malaysia but also in Vietnam. In Vietnam, land recovery aimed at socio-economic development for national or public interest is limited to projects to construct industrial parks, export processing zones, hi-tech zones, economic zones and new urban centers, investment projects funded with official development assistance (ODA) capital, and national important projects approved by the National Assembly (Article 62 of Land Law). However, in Malaysia, the area where land acquisition is possible is not limited, and unplanned land acquisition may be implemented systematically in urban planning.

\footnotetext{
${ }^{6}$ It should be noted that Malaysia's general elections in the 1990s were held in 1990, 1995, and 1999.
} 


\section{Discovery of Corruption and Bribery}

In Malaysia, the implementation of land acquisition requires the approval of State authority. However, a survey of listed companies on the Malaysian Bourse (Bursa Malaysia), "KPMG Malaysia Fraud, Bribery and Corruption Survey 2013"7 (KPMG 2013), shows the perceptions of corporate bribery and corruption when doing business in Malaysia. The relationship between bribery of state government-related parties and business licensing has become clear from the process of the trial against land acquisition ${ }^{8}$ (Stamford Holdings Sdn Bhd v. Kerajaan Negeri Johor and Ors 1998). Bribery related to the business license seems to have a meaning of starting money for the application procedure. However, given these contents of investigation, trial case, and the prior researches, it is unavoidable to be skeptical as to whether effective acquisition has been carried out after appropriate examination in all land acquisitions. ${ }^{9}$

\subsection{Legal System and Structure of Land Administration in Malaysia}

This chapter organizes the legal system and the structure of land administration in Malaysia, which are the preconditions of consideration.

\subsubsection{Legal System of Malaysia}

Malaysia has a system in which three powers are divided under the influence of English law, but it is characterized by the relative strengthening of administrative power. The jurisdiction of the court, which was stipulated to be granted by the Federal Constitution, was changed by the revision of the Federal Constitution in

\footnotetext{
${ }^{7}$ Although there is a problem that this survey does not specify the number of valid responses, it is cleared that responses were representing almost $10 \%$ of the total number of companies listed on Bursa Malaysia. The survey shows " $71 \%$ of respondents also believed that bribery and corruption is an inevitable cost of doing business whilst $64 \%$ believed that business can't be done in Malaysia without paying bribes".

${ }^{8}$ The application for land development, which had not been approved for 4 years, was approved by the state as soon as $30 \%$ equity of the company that owns the land was given to state governmentrelated parties. In the trial, persons who were in a position to procure the necessary approval of the administrative permission for development were parties to the trial as one of the respondents.

${ }^{9}$ In the 2004 general election, the eradication of corruption is put up as one of the ruling party's manifesto, and in the 2013 general election, that is listed as one of the election pledges of the ruling and opposition parties.
} 
1988 to be the jurisdiction granted by federal law. This has eliminated the independence of jurisdiction. ${ }^{10}$

\section{The Federal Constitution as Supreme Law}

Article 4(1) of the Federal Constitution indicates that the Federal Constitution is the supreme law of the Federation. The same article also shows that any law enacted after the date of independence ${ }^{11}$ and not compatible with the federal constitution will be invalid to the extent it is not compatible with the federal constitution. In addition, under Article 4 and Article 128, each federal court is granted the power of judicial review.

\section{Provision of Property Rights in the Federal Constitution}

With regard to what kind of economic policy the administration can implement, it depends on the provisions of the constitution and law that bind the administration. The Federal Constitution is the supreme law of the Federation, giving courts unconstitutional review rights and providing that laws that do not conform to the Federal Constitution are invalid to the extent that they do not. Therefore, legislation that violates the provisions of the Constitution is unconstitutional. However, in carrying out economic policies that involve the restriction of the property rights, Article 13 (1) of the Federal Constitution of Malaysia stipulates "No person shall be deprived of property save in accordance with law". The property rights is attached to the reservation of the law (Gesetzesvorbehalt), and it is possible to limit the property rights depending on the contents of the statute. For this reason, it is a provision that can be legislated to grant flexible discretion to administration regarding the restriction of property rights. The Federal Constitution of Malaysia guarantees property rights only within the limits of the law.

The same Article (2) stipulates that "No law shall provide for the compulsory acquisition or use of property without adequate compensation". ${ }^{12}$ With regard to the restriction of property rights, it is necessary to satisfy the two requirements of statutory law and adequate compensation.

\footnotetext{
${ }^{10}$ The Federal Constitution of Malaysia has been revised 57 times as of the final revision of 2009 (Constitution of Malaysia n.d.). This amendment frequency of constitution is due to the fact that the ruling coalition BN (Barison Nasional) had secured two-thirds of the parliament's seats, which is a requirement for the amendment of the Federal Constitution.

${ }^{11}$ Merdeka Day: 31 August 1957.

${ }^{12}$ The basic criterion for assessing the adequate compensation on account of land acquisition as required by Article 13 (2) of the Federal Constitution is the market price (First Schedule of Land Acquisition Act). For details, see Xavier (2002).
} 


\section{Limitation of Judicial Review}

In addition to the provision of property rights attached to the reservation of laws and enabling administrations to implement flexible policies, Malaysia has provisions to limit judicial review that make it difficult to challenge the administration. In addition to the power of judicial review, Superior Court ${ }^{13}$ is given the right of judicial review over the act of administration under First Schedule of Court Act and Order 53 of Rules of the High Court (Kuwahara 2009). However, a special clause called the "Final Clause" often excludes constitutional review and judicial review from application and limits its application. This final clause has provisions in the federal constitution itself, and also in the law (at least the income tax law provides this final clause). ${ }^{14}$ Article 8(3) of the Land Acquisition Act in Malaysia provides this final clause.

The basic principle of judicial review is the doctrine of Ultra Vires. In order to claim the invalidation of land acquired by the State government, the landowner who has acquired the land must prove that there is a mala fide or bad faith for the land acquisition. That is, the lawsuit must prove that the purpose of the acquisition is not within the scope of the requirements of Article 3 of the law that establishes the requirements for land acquisition, or that the state government has abuse of authority over land acquisition (S. Kulasingam, and Anor v. Commissioner of Lans, Federal Territory, and Ors 1982). It has been held in court that this proof is not sufficient just because there is a suspicion of allegations (Yeap Seok Pen v. Government of the State of Kelantan 1986). To claim the invalidation of arbitrary land acquisition, the landowner to be acquired must show clear evidence that there is a mala fide or bad faith.

\subsubsection{Legislation and Administrative Jurisdiction Over Land in Malaysia}

This section shows the legislative authority and administrative jurisdiction regarding the land between the Federation and State that constitute the Federation.

In the Malay Peninsula, the National Land Code 1965 is the general law for land. In Sarawak and Sabah State located in Borneo, the Sarawak Land Code 1958 and the Sabah Land Ordinance 1930 are applied to the respective States.

\footnotetext{
${ }^{13}$ Superior Courts are established under the Federal Constitution, and their decisions are "stare decisis (binding force of precedents)". Superior Courts are composed of High Court of Peninsular Malaysia, High Court of Sabah and Sarawak, Court of Appeal, and Federal Court, and the Federal Court is the court of the final trial (Kuwahara 2009).

${ }^{14}$ A typical example of the "Final Clause" is as follows: "final and conclusive", and "shall not be challenged appealed against, reviewed, quashed or called in question in any court of law" (Ömura 1997).
} 
In Malaysia, State that makes up the Federation has authority concerning land (Article 80 of Federal Constitution and Ninth Schedule List II of Federal Constitution). The alienation of land owned by State to a private person creates private ownership. Then, the land alienated from a State is bought and sold among private individuals, and the distribution of land takes place. In Malaysia, Article 80 of the Federal Constitution and Ninth Schedule of the Federal Constitution provide for the allocation of administrative authority between the Federal government and State government. Ninth Schedule List II of the Federal Constitution, which defines the legislative jurisdiction, shows that States have legislative authority with regard to land-related matters, including forced acquisition of land. For this reason, a State may enact State laws with its own regional validity concerning the matters stipulated in List II, which defines State legislative jurisdiction (Article 73 of the Federal Constitution). All matters States have legislative authority are administrative jurisdiction of that State [Article 80(1) of the Federal Constitution].

In the case of an inconsistency between a federal law and any State law, federal law shall prevail and State law shall be invalidated to the extent that it does not comply with federal law (Article 75 of the Federal Constitution). In addition, so as to unify the laws of several States, Parliament has legislative authority over matters State has legislative authority (Article 76 of the Federal Constitution). Federal law superordinates State law, and its effect extends to all parts of Malaysia (Article 73 of the Federal Constitution). These factors secure the domestic policy uniformity. However, the federal administrative authority does not extend to State administrative jurisdiction indicated by the Ninth Schedule List II of Federal Constitution [Article 80 (2) of the Federal Constitution].

With regard to the development plan covering a single State or multiple States, if, after consultation with related organizations, ${ }^{15}$ the King (Yang di-Pertuan Agong) acknowledges that the development plan will contribute to the national interest, and, after the development plan is published, the King may proclaim the area or areas as a development area, and, as a result, despite the matters that only States have a legislative power, the Federal Parliament shall be authorized to put the development plan and any part of it into effect in any matter related to the development plan (Article 92 of the Federal Constitution).

The land administration in Malaysia is based on the above-mentioned legislative and administrative jurisdiction, and except for cases where it is designated as a development area, the state government has a system of discretion. ${ }^{16}$ The state government also has the administrative authority for land acquisition (Ninth Schedule List II of the Federal Constitution and Article 80 of the Federal Constitution), and it is not possible to enact federal law contrary to this administrative jurisdiction.

\footnotetext{
${ }^{15}$ The King (Yang di-Pertuan Agong), after a recommendation from an expert committee, consults with the National Finance Council, the National Land Council, and the Government of any State concerned.

${ }^{16}$ The Federation can advise the Government of any State (Article 94 of Federal Constitution).
} 


\subsection{Consideration and Conclusion}

The provision within the limits of the law in Article 13 of the Federal Constitution in Malaysia extend the scope of human rights restriction, as compared to the case where this provision is not within the limits of the law, and may cause new legislative problems in theory. Although repeated revisions of the Federal Constitution have threatened constitutionalism, it is necessary to revise Article 13 of the Federal Constitution to reduce administrative discretion in order to prevent the easy restriction of property rights.

Constitutional provision within the limits of the law increases the degree of freedom of policies that administrations can implement. However, policies that make light of personal property will lose their institutional credibility toward the assets and reduce the people's motivation, and as a result, it is thought that economic growth will be obstructed in the long run. This matter applies not only to Malaysia but also to other countries. ${ }^{17}$ With regard to land acquisition for profit-oriented enterprises, business operator can avoid the rise in the selling price of the land that occurs in the process of negotiation for buying and selling land by utilizing land acquisition system, which gives the business operator an incentive to reduce the cost of getting land. This is a factor for the beginning of land acquisition by the business operator.

Extensive discretion of administration enables flexible administrative decisions. On the other hand, if the range of administrative discretion is large, the range in which the administration is leaded to the grant and approval of the project which has deviated from the optimum judgment of the administration for maximizing social welfare will also be enlarged. This occurs through bribery to the administration by the economic entity that tries to increase its own profit utilizing the authority of the administration. Bribery to the administration for securing and expanding private interests hinders the essential role of the administration to maximize social welfare. By this bribery, a sufficient examination cannot be carried out, and the administration can carry out erroneous grant and approval. At the time of revision of the Land Acquisition Act in 1997, ${ }^{18}$ a provision was established that the examination for the application concerning land acquisition should be conducted in consideration of the public interest and the feasibility of the project. However, the purpose of this provision may be overwhelmed by bribery to the administration.

Based on the above argument, the universal point of the negative effect factor on the legal system design concerning the grant and approval of the land acquisition (project) of the administration can be arranged into the following three points.

\footnotetext{
${ }^{17}$ It can have such an effect not only on land ownership but also on land use rights in countries where private ownership of land is not permitted.

${ }^{18}$ Under the Amendment Act of 1997, the scope of land acquisition requirements has been expanded, and it has become possible to newly acquire land for recreational purpose.
} 
1. The provision of the constitution within the limits of the law increases the degree of freedom of legislation and gives the administration broad discretion (flexible discretion).

2. For administration to have broad discretion, the administration can make decisions that have a negative effect on the accomplishment of the policy goals and decisions that undermine the public's credibility.

3. Administrative decisions that have a negative effect on the fulfillment of policy goals are elicited through bribery that seeks to exploit administrative authority having broad discretion.

Although it depends on the contents of the constitutional provisions of each country, in countries that are legislative based on the constitution and whose administration is governed by the constitution and the law, the above points are not limited to Malaysia, but can be common characteristics in other countries. It is necessary to keep in mind that administration makes mistakes and makes decisions which do not consider the expansion of social welfare. Moreover, system design in anticipation of reducing the degree of "administration failure" seems to be an important aspect in legal system design.

It can be said that further control of administrative discretion based on laws and regulations, including judicial review, is the future task of Malaysia toward becoming a developed country. It is also institutionally possible to narrow the state government's discretion by self-cleansing by the state law established by the legislature, which consists of direct election by residents.

This research considered based on the transition of policy from NEP (1971-1990) to NDP (1991-2000), but after NDP, National Vision Policy (National Vision Policy), from 2001 to 2010, the following NVP has been implemented, and a New Economic Model (New Economic Model, hereinafter NEM) has been formulated from 2010 to 2020 . The realization of the "economically fair and equal society" raised as the policy philosophy of NDP (1991-2000) is coming closer to realization in terms of income gap, as Fig. 6.3 shows, from 2007 to $2014 .{ }^{19}$ When introducing a land acquisition system for profit-oriented enterprises despite matters that can be negotiated between the parties, as the reason for establishing a land acquisition system that directly contributes to the expansion of private interests, a cause for public purposes, such as securing funds for income distribution to correct the gap, ${ }^{20}$ and promoting poverty reduction by promptly promoting economic growth, etc., is required.

The amendment of Land Acquisition Act, which also enables land acquisition for profit-oriented enterprises, took place in 1991, the first year of NDP, when the policy shifted from NEP to NDP. In the process of policy transition from NDP to NVP and

\footnotetext{
${ }^{19}$ The Gini coefficient throughout Malaysia in 2014 was 0.401 . By ethnic group in 2014, Bumiputra 0.389 , Chinese 0.405 , and Indian 0.396 .

${ }^{20}$ However, developing countries taking a parliamentary system have the possibility of distributing effectively for election votes with considering the time, place, and target people in order to reflect the outcome of economic growth as much as possible in the number of seats.
} 
Fig. 6.3 Gini Coefficient, by Ethnic Group and Whole Malaysia 1970-2014.

Source: Created by the author from Economic Planning Unit. Note: Data for 1970, 1974, 1976, 1987 Peninsular Malaysia only

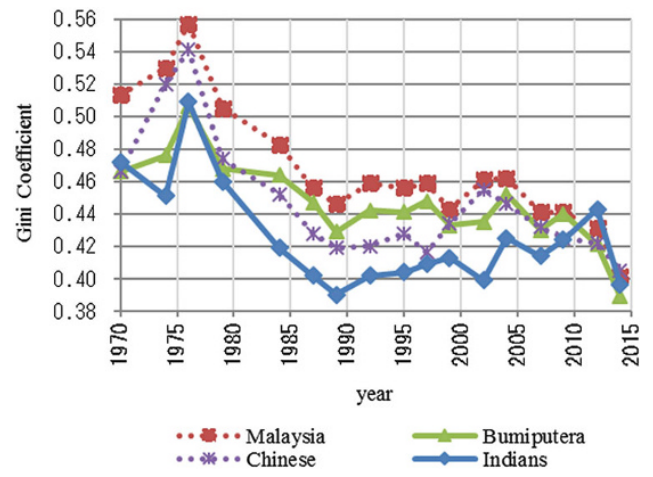

NEM, how the implementation of land acquisition changed, what kind of policies has been taken under NVP and NEM, and what kind of influence the policies have brought about each race are a future research topic.

Acknowledgments This study received valuable feedbacks from anonymous reviewers. I appreciate these feedbacks.

\section{References}

Abe Y (1996) Seisaku hōgaku no kihon shishin (Basic guidelines of policy law). KOUBUNDOU Publishers, Tokyo, pp 79-93

Alias A, Nasir Daud MD (2006) Payment of adequate compensation for land acquisition in Malaysia. Pac Rim Prop Res J 12(3):326-349

Alias A, Kamaruzzaman SN, Daud MN (2010) Traditional lands acquisition and compensation: the perceptions of the affected Aborigin in Malaysia. Int J Phys Sci 5(11):1696-1705

Beblavy M (2007) Costs of corruption and potential remedies from an economic point of view. Ekonomický časopis (J Econ) 7(55):697-711

Constitution of Malaysia (n.d.) List of amendments

Cooray A, Dzhumashev R, Schneider F (2017) How does corruption affect public debt? An empirical analysis. World Dev 90:115-127

Dell'Angelo J, D'Odorico P, Rulli MC, Marchand P (2017) The tragedy of the grabbed commons: coercion and dispossession in the global land rush. World Dev 92:1-12

Department of Statistics, Malaysia (n.d.). https://www.statistics.gov.my/. Accessed 20 Jan 2016

Economic Planning Unit, Malaysia (n.d.). http://www.epu.gov.my/en/household-income-poverty. Accessed 19 Sept 2016

Financial Times, 2 August 1991, p 4

Fujimoto A (1997) Economic development and changing land issues in Malaysia. In: Mizuno K, Shinichi S (eds) Economic development and land system in south-east Asia. Institute of Developing Economies (Japan), Chiba-shi, pp 225-262

German L, Schoneveld G, Mwangi E (2013) Contemporary processes of large-scale land acquisition in Sub-Saharan Africa: legal deficiency or elite capture of the rule of law? World Dev 48:1-18

Ghatak M, Mookherjee D (2014) Land acquisition for industrialization and compensation of displaced farmers. J Dev Econ 110:303-312 
Hirai Y (1995) A theory of legal policy making. Yuhikaku Publishing, Tokyo, pp 69-117

Hiramatsu H (2012) Chinese land expropriation schemes from the viewpoint of Japanese law. Shimane J Policy Stud 24:85-102

Ishida A (2006) A study of the land regime in Vietnam: changes in the state's land recovery system. Mon J Inst Asian Econ Aff 47(8):2-26

Jiang L (2013) Compulsory acquisition of land in China and the problems toward its realization (1). Comp Law Rev 46(4):157-188

Ju Q, Ni J, Ni D, Wu Y (2016) Land acquisition, labor allocation, and income growth of farm households. Emerg Mark Financ Trade 52(8):1744-1761

Kleemann L, Thiele R (2015) Rural welfare implications of large-scale land acquisitions in Africa: a theoretical framework. Econ Model 51:269-279

KPMG Malaysia fraud, bribery and corruption survey 2013. https://www.kpmg.com/MY/en/ IssuesAndInsights/ArticlesPublications/Documents/2013/fraud-survey-report.pdf. Accessed 29 Mar 2016

Kuwahara N (2009) Malaysia. In: Aikyō M (ed) The handbook of Asian legal systems. University of Nagoya Press, Nagoya, pp 240-266

Miyamoto K (1993) A comparative study on land acquisition system for public works in some Southeast Asian countries. J City Plan Inst Jpn 28:445-450

Miyasaka Porro N, Shiraishi Neto J (2014) Coercive harmony in land acquisition: the gendered impact of corporate "responsibility" in the Brazilian Amazon. Fem Econ 20(1):227-248

Nolte K, Voget-Kleschin L (2014) Consultation in large-scale land acquisitions: an evaluation of three cases in Mali. World Dev 64:654-668

Ōmura Y (1997) The constitutional system of Malaysia. In: Sakumoto N (ed) Constitutional system of Asian countries. Institute of Developing Economies (Japan), Chiba-shi, pp 49-84

Ooi JT, Sirmans CF (2004) The wealth effects of land acquisition. J Real Estate Financ Econ 29 (3):277-294

Pakhriazad H-Z, Shinohara T (2005) A study of legitimate rights of the Sultan and Malay customary land tenure system in the state of Pahang, Peninsular Malaysia. J For Econ 51(2):13-20

S. Kulasingam \& Anor v. Commissioner of Lans, Federal Territory \& Ors [1982], 1 MLJ 204

Salih K, Yusof ZA (1989) Overview of the new economic policy and framework for post-1990 economic policy. Malays Manag Rev 24(2):13-61

Sato H (2012) Economic development and land acquisition in India: reconsidering property rights on lands in development and the theory of eminent domain. Mon J Inst Asian Econ Aff 53 (4):113-137

Stamford Holdings Sdn Bhd v. Kerajaan Negeri Johor \& Ors [1998], 1 MLJ 607

Torii T (1996) Malaysia in 1995: Mahathir regime towards the final stage. In: Yearbook of Asian affairs. Institute of Developing Economies (Japan), Chiba-shi, pp 350-356

Tuyen TQ, Lim S, Cameron MP, Huong VV (2014) Farmland loss and livelihood outcomes: a microeconometric analysis of household surveys in Vietnam. J Asia Pac Econ 19(3):423-444

Xavier G (2002) Land acquisition in Malaysia. In: Kotaka T, Callies DL (eds) Taking land: compulsory purchase and regulation in Asian-Pacific countries. University of Hawaii Press, Honolulu, HI, pp 195-226

Yeap Seok Pen v. Government of the State of Kelantan [1986], 1 MLJ 449

Zhang K (2005) An essay on the rising and development of the overseas Chinese Enterprise Group in Malaysia. Ann Inst Asian Stud Osaka Univ Econ Law 42:17-29 
Open Access This chapter is licensed under the terms of the Creative Commons Attribution 4.0 International License (http://creativecommons.org/licenses/by/4.0/), which permits use, sharing, adaptation, distribution and reproduction in any medium or format, as long as you give appropriate credit to the original author(s) and the source, provide a link to the Creative Commons licence and indicate if changes were made.

The images or other third party material in this chapter are included in the chapter's Creative Commons licence, unless indicated otherwise in a credit line to the material. If material is not included in the chapter's Creative Commons licence and your intended use is not permitted by statutory regulation or exceeds the permitted use, you will need to obtain permission directly from the copyright holder. 